University of Nebraska - Lincoln

DigitalCommons@University of Nebraska - Lincoln

US Army Research

U.S. Department of Defense

2005

\title{
Towards an RTS,S-Based, Multi-Stage, Multi-Antigen Vaccine Against Falciparum Malaria: Progress at the Walter Reed Army Institute of Research
}

\author{
D. Gray Heppner Jr. \\ Walter Reed Army Institute of Research, Department of Immunology, 503 Robert Grant Avenue, Silver \\ Spring, MD 20910, USA
}

Kent E. Kester

Walter Reed Army Institute of Research, Department of Immunology, 503 Robert Grant Avenue, Silver Spring, MD 20910, USA

\author{
Christian F. Ockenhouse \\ Walter Reed Army Institute of Research, Department of Immunology, 503 Robert Grant Avenue, Silver \\ Spring, MD 20910, USA
}

Aladja Trisn FlaxoSmithKline Biologicals, s.a., Rixensart, Belgium

Part of the Operations Research, Systems Engineering and Industrial Engineering Commons Opokua Ofori

GlaxoSmithKline Biologicals, s.a., Rixensart, Belgium

Heppner Jr., D. Gray; Kester, Kent E.; Ockenhouse, Christian F.; Tornieporth, Nadia; Ofori, Opokua; Lyon,

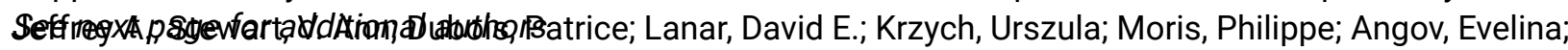
Cummings, James F.; Leach, Amanda; Hall, B. Ted; Dutta, Sheetij; Schwenk, Robert; Hillier, Collette; Barbosa, Arnoldo; Ware, Lisa A.; Nair, Lalitha; Darko, Christian A.; Withers, Mark R.; Ogutu, Bernhards; Polhemus, Mark E.; Fukuda, Mark; Pichyangkul, Sathit; Gettyacamin, Montip; Diggs, Carter; Soisson, Lorraine; Milman, Jessica; Dubois, Marie-Claude; Garcon, Nathalie; Tucker, Kathryn; Wittes, Janet; Plowe, Christopher V.; Thera, Mahamadou A.; Duombo, Ogobara K.; Pau, Maria G.; Goudsmit, Jaap; Ballou, W. Ripley; and Cohen, Joe, "Towards an RTS,S-Based, Multi-Stage, Multi-Antigen Vaccine Against Falciparum Malaria: Progress at the Walter Reed Army Institute of Research" (2005). US Army Research. 1.

https://digitalcommons.unl.edu/usarmyresearch/1

This Article is brought to you for free and open access by the U.S. Department of Defense at DigitalCommons@University of Nebraska - Lincoln. It has been accepted for inclusion in US Army Research by an authorized administrator of DigitalCommons@University of Nebraska - Lincoln. 


\section{Authors}

D. Gray Heppner Jr., Kent E. Kester, Christian F. Ockenhouse, Nadia Tornieporth, Opokua Ofori, Jeffrey A. Lyon, V. Ann Stewart, Patrice Dubois, David E. Lanar, Urszula Krzych, Philippe Moris, Evelina Angov, James F. Cummings, Amanda Leach, B. Ted Hall, Sheetij Dutta, Robert Schwenk, Collette Hillier, Arnoldo Barbosa, Lisa A. Ware, Lalitha Nair, Christian A. Darko, Mark R. Withers, Bernhards Ogutu, Mark E. Polhemus, Mark Fukuda, Sathit Pichyangkul, Montip Gettyacamin, Carter Diggs, Lorraine Soisson, Jessica Milman, MarieClaude Dubois, Nathalie Garcon, Kathryn Tucker, Janet Wittes, Christopher V. Plowe, Mahamadou A.

Thera, Ogobara K. Duombo, Maria G. Pau, Jaap Goudsmit, W. Ripley Ballou, and Joe Cohen 


\title{
Towards an RTS,S-based, multi-stage, multi-antigen vaccine against falciparum malaria: progress at the Walter Reed Army Institute of Research ${ }^{\text {is }}$
}

D. Gray Heppner Jr. ${ }^{\mathrm{a}}{ }^{*}$, Kent E. Kester ${ }^{\mathrm{a}}$, Christian F. Ockenhouse ${ }^{\mathrm{a}}$, Nadia Tornieporth ${ }^{\mathrm{b}}$, Opokua Ofori $^{\mathrm{b}}$, Jeffrey A. Lyon ${ }^{\mathrm{a}}$, V. Ann Stewart ${ }^{\mathrm{a}}$, Patrice Dubois ${ }^{\mathrm{b}, 1}$, David E. Lanar ${ }^{\mathrm{a}}$, Urszula Krzych $^{\mathrm{a}}$, Philippe Moris ${ }^{\mathrm{b}}$, Evelina Angov ${ }^{\mathrm{a}}$, James F. Cummings ${ }^{\mathrm{a}}$, Amanda Leach ${ }^{\mathrm{b}}$, B. Ted Hall ${ }^{a}$, Sheetij Dutta ${ }^{a}$, Robert Schwenk ${ }^{a}$, Collette Hillier ${ }^{\mathrm{a}}$, Arnoldo Barbosa ${ }^{\mathrm{a}}$, Lisa A. Ware ${ }^{\mathrm{a}}$, Lalitha Nair ${ }^{\mathrm{a}}$, Christian A. Darko ${ }^{\mathrm{a}}$, Mark R. Withers ${ }^{\mathrm{c}}$, Bernhards Ogutu ${ }^{\mathrm{c}}$, Mark E. Polhemus ${ }^{c}$, Mark Fukuda ${ }^{d}$, Sathit Pichyangkul ${ }^{\mathrm{d}}$, Montip Gettyacamin ${ }^{\mathrm{d}}$, Carter Diggs ${ }^{\mathrm{e}}$, Lorraine Soisson ${ }^{\mathrm{e}}$, Jessica Milman ${ }^{\mathrm{f}}$, Marie-Claude Dubois ${ }^{\mathrm{b}}$, Nathalie Garçon ${ }^{\mathrm{b}}$, Kathryn Tucker ${ }^{\mathrm{g}}$, Janet Wittes ${ }^{\mathrm{g}}$, Christopher V. Plowe ${ }^{\mathrm{h}}$, Mahamadou A. Thera ${ }^{i}$, Ogobara K. Duombo ${ }^{i}$, Maria G. Pau ${ }^{\mathrm{j}}$, Jaap Goudsmit ${ }^{\mathrm{j}}$, W. Ripley Ballou ${ }^{\mathrm{b}}$, Joe Cohen ${ }^{\mathrm{b}}$

\footnotetext{
${ }^{a}$ Walter Reed Army Institute of Research, Department of Immunology, 503 Robert Grant Avenue, Silver Spring, MD 20910, USA

${ }^{\mathrm{b}}$ GlaxoSmithKline Biologicals, s.a., Rixensart, Belgium

${ }^{\mathrm{c}}$ United States Army Medical Research Unit-Kenya, Kenya Medical Research Institute, Nairobi, Kenya

${ }^{\mathrm{d}}$ United States Army Medical Component, Armed Forces Research Institute of Medical Sciences (AFRIMS), Bangkok, Thailand

${ }^{\mathrm{e}}$ United States Agency for International Development, Washington, DC, USA

${ }^{\mathrm{f}}$ PATH's Malaria Vaccine Initiative, Bethesda, MD, USA

${ }^{g}$ Statistics Collaborative Incorporated, Washington, DC, USA

${ }^{\mathrm{h}}$ Center for Vaccine Development, University of Maryland, Baltimore, MD, USA

${ }^{\mathrm{i}}$ Malaria Research and Training Center, University of Bamako, Bamako, Mali

j Crucell Holland, B.V., Leiden, The Netherlands
}

\begin{abstract}
The goal of the Malaria Vaccine Program at the Walter Reed Army Institute of Research (WRAIR) is to develop a licensed multi-antigen, multi-stage vaccine against Plasmodium falciparum able to prevent all symptomatic manifestations of malaria by preventing parasitemia. A secondary goal is to limit disease in vaccinees that do develop malaria. Malaria prevention will be achieved by inducing humoral and cellular immunity against the pre-erythrocytic circumsporozoite protein (CSP) and the liver stage antigen-1 (LSA-1). The strategy to limit disease will target immune responses against one or more blood stage antigens, merozoite surface protein-1 (MSP-1) and apical merozoite antigen-1 (AMA-1). The induction of T- and B-cell memory to achieve a sustained vaccine response may additionally require immunization with an adenovirus vector such as adenovirus serotype 35. RTS,S, a CSP-derived antigen developed by GlaxoSmithKline Biologicals in collaboration with the Walter Reed Army Institute of Research over the past 17 years, is the cornerstone of our program. RTS,S formulated in AS02A (a GSK proprietary formulation) is the only vaccine candidate shown in field trials to prevent malaria and, in one instance, to limit disease severity. Our vaccine development plan requires proof of an individual antigen's efficacy in a Phase 2 laboratory challenge or field trial prior to its integration into an RTS,S-based, multi-antigen vaccine. Progress has been accelerated through extensive partnerships with industrial,
\end{abstract}

\footnotetext{
Tresented in part at the World Congress on Vaccines and Immunology, Tsukuba City, Japan, 5 October, 2004.

* Corresponding author. Tel.: +1 301319 9414; fax: +1 3013197358.

E-mail address: donald.heppner@na.amedd.army.mil (D.G. Heppner Jr.).

1 Present address: ImmunoVacc Consulting, Brussels, Belgium.
} 
academic, governmental, and non-governmental organizations. Recent safety, immunogenicity, and efficacy trials in the US and Africa are presented, as well as plans for the development of a multi-antigen vaccine.

(C) 2005 Published by Elsevier Ltd.

\section{Introduction}

The Walter Reed Army Institute of Research (WRAIR) in Silver Spring, Maryland is dedicated to developing drugs, diagnostic devices, and vaccines to protect military personnel against disease, particularly tropical diseases such as malaria [1]. Military medical research has led to the development and field-testing of anti-malarial drugs including mefloquine, primaquine, doxycycline, atovaquone-proguanil (Malarone), tafenoquine, and halofantrine that are active against drugresistant strains of Plasmodium falciparum [2]. These antimalarial drugs have demonstrated substantial public health benefit. Despite the availability of modern antimalarial drugs, mosquito-repellants, bed nets and other countermeasures, malaria threatens the success of modern militaries, most recently Australian and Thai forces in East Timor (2000), British troops in Sierra Leone (2001) and the US Marines in Liberia (2003). The US military requires a safe, welltolerated highly effective vaccine that prevents malaria or very significantly limits the severity of disease in vaccinees who develop malaria, and confers sustained protection. Endemic populations suffer some 3 million deaths and 500 million episodes of this dread disease annually [3]. A vaccine with this profile may also be of potential public health benefit to these populations. Recent excellent reviews broadly address the status of current malaria vaccine efforts, considerations in vaccine design, and the formidable obstacles to vaccine development [4-6]. This brief article focuses on the successful WRAIR-GSK partnership that led to the RTS,Sbased malaria vaccine candidates, the results and implications of recent RTS,S/AS02A clinical and field trials, and then outlines plans to develop an RTS,S-based multi-antigen, multistage malaria vaccine that would fulfill the requirements of the US military.

\section{Development of RTS,S}

\subsection{Initial circumsporozoite protein vaccines}

The gene coding for the circumsporozoite protein (CSP) was the first $P$. falciparum gene to be identified and cloned [7]. The CS proteins of all malaria species contain a central segment of species-specific amino acid repeat sequences flanked by non-repeat regions $[8,9]$. In the case of $P$. falciparum, the central portion contains approximately 40 repeats of the amino acid sequence asparagin-alanine-asparagines-proline (NANP) and several asparagines-valine-aspartic acid-proline (NVDP) repeats [10]. The central repeating region contains immunodomi- nant B-cell epitope(s) [11], whereas the majority of epitopes responsible for the induction of $\mathrm{CD} 4$ and CD8 T-cells are located within the flanking regions. Two alum-adjuvanted candidate vaccines based on the CSP repeat sequences were developed in the mid 1980s [12], tested in humans at the University of Maryland [13] and at WRAIR [14], and found to be safe; however, both suffered from generally poor immunogenicity. In most volunteers, repeated immunization induced relatively low titers of antibodies against the repeat region of the CSP. Nevertheless, a small number of volunteers who did respond well were protected against homologous experimental sporozoite challenge. These encouraging challenge data served as a proof of concept that antibody-mediated sterile immunity against malaria could be induced in humans by immunization with a recombinant or synthetic pre-erythrocytic stage subunit vaccine. In these studies with a limited number of volunteers, protection seemed to be associated with high antibody levels; therefore, it was assumed that the development of more immunogenic versions of these vaccines would lead to better efficacy. Subsequent sporozoite vaccines, also based on the NANP repeats, contained modifications conducive to the enhancement of humoral immune responses, such as conjugation of recombinant CSP repeat region with Pseudomonas aeruginosa exotoxin A (R32ToxA)[15] and formulation of a similar antigen (R32NS1) in liposomes containing monophosphoryl lipid A (MPL)[16] or an emulsion of MPL, mycobacterial cell wall skeleton, and squalene (Detox ${ }^{\circledR}$, Ribi Immunochem) $[17,18]$. Each of these strategies resulted in generally higher antibody levels, but surprisingly did not significantly enhance efficacy upon live sporozoite challenge [19-21], thus suggesting that antibody responses to NANP repeats were not alone sufficient to induce significant protective efficacy.

\subsection{WRAIR-GSK development of RTS,S}

While these clinical studies were in progress, the role of protective T-cell responses directed against the liverstage form of the parasite was elucidated in greater detail. Studies in rodents and humans immunized with irradiated sporozoites revealed that not only antibodies, but also CD4 and CD8 cells that exhibited cytotoxic T-cell (CTL) responses or produced cytokines such as interferon- $\gamma$ were important components of the protective immune network against the pre-erythrocytic stage of $P$. falciparum [22]. Target epitopes for these T-cells have been localized to the Cterminal region of the CSP [23-26]. The recognition that peptide sequences lying outside the CSP repeat were important for induction of humoral and cellular responses against the hepatic stage led to the inclusion of non-repeat 
portions of the molecule in the next generation of CSP-based vaccines.

In 1984, GlaxoSmithKline in collaboration with WRAIR pioneered the use of the hepatitis B surface antigen (HB$\mathrm{sAg}$ ) as a carrier matrix for the central repeat region of the $P$. falciparum CSP [27]. The initial construct, referred to as R16-HBsAg, was formulated with alum; it proved safe and immunogenic in 20 hepatitis B-seronegative adults at the University of Nijmegen [28]. In 1987, following the recognition of the potential role of cell-mediated immunity and of non-repeat sequence of CSP, a new CSP-HBsAg fusion protein was developed at GSK, which incorporated the CSP C-terminal flanking region known to contain B- and T-cell epitopes into a chimeric gene expressed in Saccharomyces cerevisiae. This construct was named "RTS" to indicate the presence of the CSP repeat region (R), T-cell epitopes (T), and the hepatitis B surface antigen (S). Exigencies of purification led to the co-expression and purification of additional antigen in a ratio of RTS to S of 1:4, hence the name "RTS,S." A process compatible with GMP manufacturing of RTS,S was then developed at GSK.

\subsection{First trials of RTS,S}

The first clinical trial of RTS,S evaluated two formulations developed at GSK for safety and efficacy in malaria naïve adults in 1992 at the Walter Reed Army Institute of Research, The formulations were RTS,S and alum $(N=10)$, and RTS,S with monophosphoryl lipid A and alum $(N=10)$. Both vaccines proved to be safe and well tolerated. RTS,S/MPL/alum elicited higher antibody responses against the CSP repeat and C-terminal region than did RTS,S/alum. After sporozoite challenge, zero of six RTS,S/alum vaccinees and two of eight RTS,S/MPL/alum vaccinees were protected [29]. These encouraging results were considered to warrant further improvement of the vaccine. Consequently, GSK and WRAIR initiated a rigorous comparative preclinical safety and immunogenicity evaluation of six GSK proprietary formulations of RTS,S in rhesus monkeys at the Armed Forces Research Institute of Medical Sciences to improve upon both the humoral and cell-mediated immunogenicity of RTS,S/MPL/alum. One formulation, consisting of RTS,S formulated in an oil-in-water emulsion with MPL and QS21, demonstrated superior antibody and delayed type hypersensitivity responses, and is today designated RTS,S/AS02A [30].

\subsection{First trials of RTS,S/ASO2}

In 1996, volunteers immunized with either RTS,S/AS03 (an oil-in-water emulsion without additional adjuvants) or RTS,S/AS02A in a Phase 2A trial at WRAIR developed the highest anti-repeat antibody responses ever induced by a CS-based vaccine, but RTS,S/AS02A induced a higher T-cell response as measured by IFN- $\gamma$ production in an ELISPOT assay [31]. Following laboratory-based sporo- zoite challenge, the RTS,S/AS03 formulation was marginally protective (two of seven); in contrast, RTS,S/AS02A protected an unprecedented six of seven volunteers [32]. A single determination of the duration of protection 6 months after initial challenge found that only one of five previously protected RTS,S/AS02A-immunized volunteers was still protected [33]. Preliminary dose optimization studies at WRAIR have since confirmed that two or three doses of RTS,S/AS02A consistently confer significant protection (sterile immunity) and significant delays in the prepatent period in RTS,S/AS02A vaccinees who develop malaria as compared to concurrent infectivity controls [34].

\subsection{Lyophilized RTS,S}

After stability testing revealed a limited shelf life of RTS,S in the AS02A adjuvant, RTS,S was reformulated at GSK as a stable frozen lyophilized cake and filled in single dose vials for reconstitution with AS02A just prior to injection. A comparative trial at WRAIR demonstrated the equivalent safety and immunogenicity of the liquid and lyophilized preparations. Further, lyophilized RTS,S formulated with AS02A provided equivalent protection against experimental malaria challenge as well as the earlier liquid RTS,S/AS02A formulation (Kester, unpublished results). Subsequent trials of RTS,S have all been performed with the lyophilized version.

\subsection{Accelerated RTS,S/ASO2A schedules}

During initial trials, the RTS,S/AS02A vaccine was administered on a 0-, 1- and 6-9-months schedule. Subsequently, a Phase 2A trial at WRAIR compared the safety, immunogenicity and efficacy of lyophilized RTS,S, formulated with AS02A on two different accelerated schedules. Forty volunteers received a full dose of RTS,S/AS02A on either a $0-, 1$ - and 3-months schedule $(N=20)$ or on a $0-, 7-$, and 28-days schedule $(N=20)$. Following standard sporozoite challenge, 45 and $38 \%$, respectively, of vaccinees were completely protected against malaria and there was no increase in reactogenicity versus historical controls (Kester, unpublished results). These data provided support for subsequent accelerated schedules of evaluation for RTS,S/AS02A in Africa and for other candidate antigens adjuvanted with AS02A at WRAIR.

\subsection{RTS,S/ASO2A field trials}

The initial trial of RTS,S/AS02A, conducted by the Medical Research Council (MRC) in The Gambia in healthy adult males, demonstrated unprecedented effects, namely a $34 \%$ reduction in instance of first parasitemia (95\% CI 8-53\%; $p=0.014$ ) over a 16-weeks efficacy period [35,36], and efficacy appeared not to be strain specific [37]. Subsequently, GSK and the Malaria Vaccine Initiative at PATH (MVI) 
entered into a partnership that has sponsored the initiation of pediatric clinical development of RTS,S/AS02A. In initial pediatric studies conducted by the MRC in The Gambia and CISM in Mozambique, the vaccine was shown to be safe and highly immunogenic in children 1-11 years of age (Bojang et al., submitted for publication; Macete et al., submitted for publication). In the recently reported Phase 2B efficacy study conducted by CISM and the University of Barcelona in Mozambique, it was reported that over a 6-months period in children 1-4 years of age, RTS,S/AS02A conferred $30 \%$ (95\% CI $12-45 \%$; $p=0.004$ ) efficacy for first clinical episodes and 58\% (95\% CI 16-81\%; $p=0.019)$ efficacy for severe malaria due to P. falciparum [38]. Longitudinal followup is in progress to define the long-term safety and the magnitude and duration of RTS,S/AS02A's benefit in young children, and studies are planned to develop an RTS,S vaccine for infants in conjunction with the Expanded Program on Immunisation [39].

\section{Potential RTS,S improvements}

Until the correlates of vaccine-induced protective immunity are known, Phase 2A challenge and Phase 2B field trials will be required to confirm the efficacy of particular improvement strategies. Decision points for integrating improvements are listed in Table 1.

\subsection{RTS,S efficacy}

Efficacy estimates for Phase 2A trials of RTS,S/AS02A based only on the occurrence of parasitemia overlook the important biologic effect represented by the consistent prolongation of the prepatent period in RTS,S/AS02A vaccinees. In recent trials, approximately $40 \%$ of adult volunteers immunized with two or three doses of RTS,S/AS02A experience complete protection and an additional $40-45 \%$ note a roughly 2 days delay in the pre-patent period when compared to simultaneous infectivity controls. This effect is attributable to either a reduction of viable sporozoites or to an interruption of hepatic schizogony or both resulting in a significant reduction in the release of hepatic merozoites $[34,40]$. Encouraged by these results, we have embarked on parallel development efforts to augment RTS,S/AS02A efficacy.

\subsection{RTS,S and an adenovirus vector}

In 1997, scientists at New York University's (NYU) School of Medicine first reported in a series of publications that a recombinant adenovirus expressing the CSP generated sustained protection in mice against lethal challenge with $P$. yoelii sporozoites by a variety of immune mechanisms [41-43]. Later, in a joint effort between NYU and Crucell, a biotechnology company in the Netherlands, it was shown that a novel recombinant adenovirus 35 vector expressing CSP also protected mice against $P$. yoelli (Goudsmit, unpublished). The recombinant adenovirus 35 is a non-replicating viral vector chosen for clinical vaccine development because there is minimal worldwide seroprevalence of neutralizing antibody that would interfere with its use as a vaccine [44-47]. Recently, a collaboration between Crucell, GSK, and WRAIR was established for the purpose of testing an adenovirus 35 (Ad 35) CSP vaccine directed against $P$. falciparum, designated Ad $35 \mathrm{CS}$ as well as the combination of Ad 35 CS and RTS,S in a so called "prime/boost" regimen. Thus, in 2003 preclinical evaluations began of Ad 35 CS alone and in combination with RTS,S in the standard rhesus monkey safety and immunogenicity model at WRAIR. Contingent upon the results of this study, Phase 2A clinical trials are planned for 2006, with the support of the National Institute of Allergy and Infectious Diseases.

\subsection{RTS,S with additional antigens}

We expect that the efficacy of an RTS,S-based malaria vaccine could be improved by combination with one or more protective antigens. Our vaccine development strategy is first to establish a protective effect of additional protein antigens prior to co-formulating them with RTS,S as a combined, multi-antigen vaccine.

\subsubsection{Merozoite surface protein-1 (MSP-1)}

Merozoite surface protein-1, the first antigen discovered on the surface of erythrocytic stage merozoites, is also expressed in all generations of merozoites, including those released at the end of hepatic schizogony [48]. The C-terminal portion of the MSP-1 is the target of protective immunity as suggested by epidemiological studies $[49,50]$ and as demonstrated by the protection of Aotus monkeys against malaria challenge by immunization with $42-\mathrm{kDa}$ C-terminal MSP-1

Table 1

Scheduled evaluation of potential RTS,S improvements

\begin{tabular}{|c|c|c|c|c|}
\hline Technology & Rationale & Example & Criteria and location & Decision date \\
\hline Antigen & Target hepatic stage parasites & Liver stage antigen-1 (LSA-1) & Phase $2 \mathrm{~A}$ at WRAIR & 2006 \\
\hline Antigen & Target blood stage & Merozoite surface protein-1 (MSP-1) & Phase $2 \mathrm{~B}$ in Kenya & 2006 \\
\hline Antigen & Target blood stage & Apical merozoite antigen-1 (AMA-1) & Phase $2 \mathrm{~B}$ in Mali & 2007 \\
\hline Vector & Increase magnitude and duration of CMI & Adeno 35/full length CSP (Ad 35 CS) & Phase $2 \mathrm{~A}$ at WRAIR & 2007 \\
\hline
\end{tabular}

CMI: cell-mediated immunity; Phase 2A: preliminary vaccine efficacy trial against experimental malaria challenge; Phase $2 \mathrm{~B}$ : preliminary vaccine efficacy trial in malaria endemic country; CSP: circumsporozoite protein; and Adeno 35: adenovirus serotype 35. 
recombinant protein [51,52]. In the late 1990s, with sustained support from the USAID and in the context of the GSK/WRAIR collaborations, a 42-kDa C-terminal MSP-1 protein based on the P. falciparum 3D7 clone was manufactured to GMP standards at the WRAIR [53]. In preclinical [54] and Phase 1 trials at WRAIR, MSP-1 formulated with AS02A proved to be safe and highly immunogenic, eliciting high titer antibodies as measured by ELISA and by immunofluorescence assay against parasitized red blood cells, as well as T-cell responses characterized by IFN- $\gamma$ production. The volunteers also produced functional antibody as measured by an in vitro growth inhibition assay (Ockenhouse, unpublished). A subsequent Phase 2A trial at WRAIR tested MSP-1/AS02A alone and in combination with RTS,S/AS02A. MSP-1/AS02A alone did not delay parasitemia, and in combination with RTS,S/AS02A it did not improve upon or interfere with the protective efficacy of RTS,S/AS02A. The trial design required treating volunteers as soon as they developed a detectable parasitemia, and thus the data did not allow determination as to whether or not MSP-1/AS02A would limit parasitemia and disease (Cummings, unpublished). Next, the MVI, USAID, GSK, WRAIR and the Kenya Medical Research Institute (KEMRI) conducted Phase 1 trials of the MSP-1/AS02A in adults and in children in malaria endemic Western Kenya from 2002 to 2004. In parallel, and with the additional support of the NIAID, University of Bamako investigators completed an additional Phase 1 safety and immunogenicity trial of MSP1/AS02A in healthy adults in Bandiagara, Mali in 2004. On the basis of the favorable safety and immunogenicity data for MSP-1/AS02A, an independent Data Safety Monitoring Board recommended proceeding to a Phase $2 \mathrm{~B}$ trial in children ages 1-4 years. This trial will commence in 2005, with support from MVI, USAID, and GSK, and will evaluate vaccine efficacy against clinical disease in children in Western Kenya.

\subsubsection{Apical merozoite antigen-1 (AMA-1)}

Apical merozoite antigen-1 (AMA-1), originally identified as a blood stage protein, is an essential antigen [55] expressed in sporozoite [56], late stage hepatic parasites [57], and in erythrocytic merozoites. AMA-1, like MSP-1, is the target of protective immunity, as supported by epidemiological observations [58], in vitro demonstrations [55], and by protection studies in which mice [59] or monkeys [60] immunized with recombinant forms of AMA-1 were protected from lethal challenge with homologous parasites. Scientists at the WRAIR have produced a correctly folded GMP recombinant protein in E. coli based upon the $P$. falciparum 3D7 strain AMA-1 ectodomain [61]. This antigen was vialed as a single-dose lyophilized cake intended for formulation with AS02A just prior to administration. In the context of the GSK/WRAIR collaboration, a Phase 1A doseescalating trial was conducted at WRAIR's Clinical Trials Center in 2003. Twenty-three healthy adult volunteers received three intramuscular doses of AMA-1 formulated with
AS02A adjuvant on a 0-, 1-, and 2-months schedule. AMA1/AS02A proved safe and immunogenic. Volunteers developed parasite-specific antibody by IFA, functional antibody as measured by an in vitro growth inhibition assay, and cellular responses as measured by lymphoproliferative and IFN- $\gamma$ responses by ELISPOT assays (Polhemus, unpublished). Two additional trials of AMA-1/AS02A are underway. A Phase 1B controlled trial in Bandiagara, Mali, supported by the National Institute of Allergy and Infectious Diseases and led by investigators from the University of Bamako, is underway to evaluate two different doses of AMA-1/AS02A in healthy adults on a 0-, 1-, and 2-months schedule. A Phase 2B trial of AMA-1/AS02A in children at risk of disease with the primary endpoint of clinical disease is planned for 2006 in West Africa.

\subsubsection{Liver stage antigen-1 (LSA-1)}

Liver stage antigen-1 was identified as a potential vaccine antigen in 1990 [62]. There are no accepted homologues of this P. falciparum antigen in murine or simian plasmodia. Therefore, the case for LSA- 1 as a vaccine candidate rests upon strong epidemiological correlations of immune responses with clinical immunity to malaria in malaria-endemic populations, and with the correlation of acquired LSA-1 immune responses with protection in irradiated sporozoite immunization studies [63]. WRAIR scientists have produced $E$. coli-expressed recombinant $P$. falciparum LSA-1 protein under GMP conditions as a candidate malaria vaccine. In 2004, WRAIR partnered with GSK and PATH's Malaria Vaccine Initiative to develop LSA-1 as a vaccine [64]. Phase 2A trials are planned for late 2005/early 2006 at WRAIR's Clinical Trials Center that will evaluate the safety, immunogenicity and efficacy of LSA-1.

\section{Conclusion}

RTS,S/AS02A, the candidate malaria vaccine in the most advanced stage of development, is the result of a sustained 17-years effort by partners committed to the development of a malaria vaccine. The immunologic correlates of RTS,Sinduced protection have not been identified yet but trends have begun to emerge, allowing more rational development to supplant empiricism, and to enable a greater focus of resources on the most promising potential improvements of RTS,S. The recent report that RTS,S/AS02A had a significant positive impact on clinical and severe malaria in children in Mozambique strongly support our working hypothesis that a more effective RTS,S-based vaccine could be developed that would better meet the US Army military needs and perhaps also benefit global public health needs.

\section{Acknowledgement}

Potential conflicts of interest statement: Christian Darko, Lalitha Nair, Lisa Ware, Collette Hillier, Jeffrey Lyon, 
Evelina Angov, David Lanar and Sheetij Dutta hold patents for the production and formulation of one or more discussed protein vaccine candidates (i.e. MSP-1, LSA-1, and AMA-1). Drs. Ripley Ballou and Joe Cohen are employees of GlaxoSmithKline Biologicals, the manufacturer of RTS,S and of the discussed proprietary adjuvant AS02A. Joe Cohen and Nathalie Garçon are listed as inventors of patented malaria vaccine and adjuvant formulations; however neither individual hold the patent for a malaria vaccine or for adjuvant formulations. Drs. Maria Pau and Jaap Goudsmit are employees of Crucell, the manufacturer of the described adenovirus vector proposed for a malaria vaccine. Drs. Stewart and Heppner have filed patent applications for the use of vaccines described in this article.

Financial support: This work was supported by the Military Infectious Diseases Program and by the United States Army Medical Materiel Development Activity of the US Army Medical Research and Materiel Command, Fort Detrick, MD, USA, the United States Agency for International Development (USAID), the National Institutes of Allergy and Infectious Diseases, GlaxoSmithKline Biologicals and the Program for Appropriate Technology in Health's Malaria Vaccine Initiative (MVI).

Disclaimer: The views of the authors do not purport to reflect the position of the Department of the Army or the Department of Defense. The US Government has the right to retain a non-exclusive, royalty-free license in and to any copyright covering this paper.

\section{References}

[1] http://wrair-www.army.mil (cited 1 January 2005).

[2] Saving lives, buying time: economics of malaria drugs in an age of resistance. Institute of Medicine of the National Academies. National Academy Press, 2004.

[3] Breman JG, Alilio MS, Mills A. Conquering the intolerable burden of malaria: what's new, what's needed: a summary. Am J Trop Med Hyg 2004;71(2 Suppl):1-15.

[4] Ballou WR, Arevalo-Herrera M, Carucci D, Richie TL, Corradin G, Diggs C, et al. Update on the clinical development of candidate malaria vaccines. Am J Trop Med Hyg 2004;71(2 Suppl):239-47.

[5] Tongren JE, Zavala F, Roos DS, Riley EM. Malaria vaccines: if at first you don't succeed. Trends Parasitol 2004;20(12):604-10.

[6] Webster D, Hill AVS. Progress with new malaria vaccines. Bull World Health Organ 2003;81(12):902-9.

[7] Dame JB, Williams JL, McCutchan TF, Weber JL, Wirtz RA, Hockmeyer WT, et al. Structure of the gene encoding the immunodominant surface antigen on the sporozoite of the human malaria parasite Plasmodium falciparum. Science 1984;225(4662):593-9.

[8] Egan JE, Weber JL, Ballou WR, Hollingdale MR, Majarian WR, Gordon DM, et al. Efficacy of murine malaria sporozoite vaccines: implications for human vaccine development. Science 1987;236:453-6.

[9] Sadoff JC, Ballou WR, Baron LS, Majarian WR, Brey RN, Hockmeyer WT, et al. Oral Salmonella typhimurium vaccine expressing circumsporozoite protein protects against malaria. Science 1988;240:336-8.

[10] Enea V, Ellis J, Zavala F, Arnot DE, Asavanich A, Masuda A, et al. DNA cloning of Plasmodium falciparumcircumsporozoite gene: amino acid sequence of repetitive epitope. Science 1984;225:628-30.
[11] Burkot TR, Da ZW, Geysen HM, Wirtz RA, Saul A. Fine specificities of monoclonal antibodies against the Plasmodium falciparumcircumsporozoite protein: recognition of both repetitive and non-repetitive regions. Parasite Immunol 1991;13:161-70.

[12] Young JF, Hockmeyer WT, Gross M, Ballou WR, Wirtz RA, Trosper $\mathrm{JH}$, et al. Expression of Plasmodium falciparum circumsporozoite protein in Escherichia coli for potential use in a human malaria vaccine. Science 1985;228:958-62.

[13] Herrington DA, Clyde DF, Losonsky G, Cortesia M, Murphy JR, Davis J, et al. Safety and immunogenicity in man of a synthetic peptide malaria vaccine against Plasmodium falciparumsporozoites. Nature 1987;328:257-9.

[14] Ballou WR, Hoffman SL, Sherwood JA, Hollingdale MR, Neva FA, Hockmeyer WT, et al. Safety and efficacy of a recombinant DNA Plasmodium falciparumsporozoite vaccine. Lancet 1987;i:1277-81.

[15] Fries LF, Gordon DM, Schneider I, Beier JC, Long GW, Gross M, et al. Safety, immunogenicity, and efficacy of a Plasmodium falciparumvaccine comprising a circumsporozoite protein repeat region peptide conjugated to Pseudomonas aeruginosatoxin A. Infect Immun 1992;60:1834-9.

[16] Fries LF, Gordon DM, Richards RL, Egan JE, Hollingdale MR, Gross M, et al. Liposomal malaria vaccine in humans: a safe and potent adjuvant strategy. Proc Natl Acad Sci USA 1992;89:35862.

[17] Ribi E, et al. Biological activities of monophosphoryl lipid A. In: Levine L, Bonventre PF, Morello IA, et al., editors. Microbiology. Washington: American Society for Microbiology; 1986.

[18] Hoffman SL, Edelman R, Bryan JP, Schneider I, Davis J, Sedegah $\mathrm{M}$, et al. Safety, immunogenicity, and efficacy of a malaria sporozoite vaccine administered with monophosphoryl lipid A, cell wall skeleton of mycobacteria, and squalene as adjuvant. Am J Trop Med Hyg 1994;51:603-12.

[19] Sherwood JA, Oster CN, Adoyo-Adoyo M, Beier JC, Gachihi GS, Nyakundi PM, et al. Safety and immunogenicity of a Plasmodium falciparum sporozoite vaccine: boosting of antibody response in a population with prior natural exposure. Trans R Soc Trop Med Hyg 1991;85:336-40.

[20] Sherwood JA, Copeland RS, Taylor KA, Abok K, Oloo AJ, Were $\mathrm{JB}$, et al. Plasmodium falciparum circumsporozoite vaccine immunogenicity and efficacy trial with natural challenge quantitation in an area of endemic human malaria of Kenya. Vaccine 1996;14(8):817-27.

[21] Brown AE, Singharaj P, Webster HK, Pipithkul J, Gordon DM, Boslego JW, et al. Safety, immunogenicity and limited efficacy study of a recombinant Plasmodium falciparum circumsporozoite vaccine in Thai soldiers. Vaccine 1994;12:102-8.

[22] Schofield L, Villaquiran J, Ferreira A, Schellekens H, Nussenzweig R, Nussenzweig V. Interferon-gamma, CD8+ T cells and antibodies required for immunity to malaria sporozoites. Nature 1987;330:664-6.

[23] Good MF, Pombo D, Quakyi IA, Riley EM, Houghten RA, Menon A, et al. Human T-cell recognition of the circumsporozoite protein of Plasmodium falciparum: immunodominant T-cell domains map to the polymorphic regions of the molecule. Proc Natl Acad Sci USA 1998;85:1199-203.

[24] Good MF, Pombo D, Quakyi IA, Riley EM, Houghten RA, Menon A, et al. Cytotoxic T cells specific for the circumsporozoite protein of Plasmodium falciparum. Nature 1988;334:258-60.

[25] Sinigaglia F, Guttinger M, Kilgus J, Doran DM, Matile H, Etlinger $\mathrm{H}$, et al. A malaria T-cell epitope recognized in association with most mouse and human MHC class II molecules. Nature 1988;336:778-80.

[26] Sinigaglia F, Matile H, Pink JR. Plasmodium falciparum specific human $\mathrm{T}$ cell clones: evidence for helper and cytotoxic activities. Eur J Immunol 1987;17:187-92.

[27] Rutgers T, Gordon D, Gatoye AM, Hollingdale M, Hockmeyer W, Rosenberg M, et al. Hepatitis B surface antigen as carrier matrix for 
the repetitive epitope of the circumsporozoite protein of Plasmodium falciparum. Biotechnology 1988;6:1065-70.

[28] Vreden SGS, Verhave JP, Oettinger T, Sauerwein RW, Meuwissen JH. Phase I clinical trial of a recombinant malaria vaccine consisting of the circumsporozoite repeat region of Plasmodium falciparum coupled to hepatitis B surface antigen. Am J Trop Med Hyg 1991;45:533-8.

[29] Gordon DM, McGovern TW, Krzych U, Cohen JC, Schneider I, LaChance R, et al. Safety, immunogenicity and efficacy of a recombinantly produced Plasmodium falciparum circumsporozoite protein/HBsAg subunit vaccine. J Infect Dis 1995;171:1576-85.

[30] Garcon N, Heppner DG, Cohen J. Development of RTS,S/AS02: a purified subunit-based malaria vaccine candidate formulated with a novel adjuvant. Expert Rev Vaccines 2003;2:231-8.

[31] Sun P, Schwenk R, White K, Stoute JA, Cohen J, Ballou WR, et al. Protective immunity induced with malaria vaccine, RTS,S, is linked to Plasmodium falciparum circumsporozoite protein-specific $\mathrm{CD} 4(+)$ and $\mathrm{CD} 8(+) \mathrm{T}$ cells producing IFN-gamma. J Immunol 2003;171(12):6961-7.

[32] Stoute JA, Slaoui M, Heppner DG, Momin P, Kester KE, Desmons $\mathrm{P}$, et al. A preliminary evaluation of a recombinant circumsporozoite protein malaria vaccine against Plasmodium falciparum. N Engl J Med 1997;336:86-91.

[33] Stoute JA, Kester KE, Krzych U, Wellde BT, Hall T, White K, et al. Long-term efficacy and immune responses following immunization with the RTS,S malaria vaccine. J Infect Dis 1998;178:1139-44.

[34] Kester KE, McKinney DA, Tornieporth N, Ockenhouse CF, Heppner DG, Hall T, et al. Efficacy of recombinant circumsporozoite protein vaccine regimens against experimental Plasmodium falciparum malaria. J Infect Dis 2001;183:640-7.

[35] Doherty JF, Pinder M, Tornieporth N, Carton C, Vigneron L, Milligan $\mathrm{P}$, et al. A Phase I safety and immunogenicity trial with the candidate malaria vaccine, RTS,S/SBAS2, in semi-immune adults in The Gambia. Am J Trop Med Hyg 1999;61:865-8.

[36] Bojang KA, Milligan PJ, Pinder M, Vigneron L, Alloueche A, Kester KE, et al. Efficacy of RTS,S/AS02 malaria vaccine against Plasmodium falciparum infection in semi-immune adult men in The Gambia: a randomised trial. Lancet 2001;358:1927-34.

[37] Alloueche A, Milligan P, Conway DJ, Pinder M, Bojang K, Doherty T, et al. Protective efficacy of the RTS,S/AS02 Plasmodium falciparum malaria vaccine is not strain specific. Am J Trop Med Hyg 2003;68:97-101.

[38] Alonso PL, Sacarlal J, Aponte JJ, et al. Efficacy of the RTS,S/AS02A vaccine against Plasmodium falciparum infection and disease in young African children: randomised controlled trial. Lancet 2004;364(9443):1411-20.

[39] http://www.malariavaccine.org/files/010301-MVI-GSK-2-27.htm (cited 1 January 2005).

[40] Davis JR, Murphy JR, Baqar S, Clyde DF, Herrington DA, Levine MM. Estimate of anti-Plasmodium falciparum sporozoite activity in humans vaccinated with synthetic circumsporozoite protein (NANP)3. Trans R Soc Trop Med Hyg 1989;83:748-50.

[41] Rodrigues EG, Zavala F, Eichinger D, Wilson JM, Tsuji M. Single immunizing dose of recombinant adenovirus efficiently induces CD8+ T cell-mediated protective immunity against malaria. J Immunol 1997;158(3):1268-74.

[42] Rodrigues EG, Zavala F, Nussenzweig RS, Wilson JM, Tsuji M. Efficient induction of protective anti-malaria immunity by recombinant adenovirus. Vaccine 1998;16(19):1812-7.

[43] Rodrigues EG, Claassen J, Lee S, Wilson JM, Nussenzweig RS, Tsuji M. Interferon-gamma-independent CD8+ T cell-mediated protective anti-malaria immunity elicited by recombinant adenovirus. Parasite Immunol 2000;22(3):157-60.

[44] Barouch DH, Pau MG, Custers JH, Koudstaal W, Kostense S, Havenga MJ, et al. Immunogenicity of recombinant adenovirus serotype 35 vaccine in the presence of pre-existing anti-Ad5 immunity. J Immunol 2004;172(10):6290-7.
[45] Kostense S, Koudstaal W, Sprangers M, Weverling GJ, Penders G, Helmus N, et al. Adenovirus types 5 and 35 seroprevalence in AIDS risk groups supports type 35 as a vaccine vector. AIDS 2004;18(8):1213-6.

[46] Tatsis N, Ertl HC. Adenoviruses as vaccine vectors. Mol Ther 2004;10(4):616-9.

[47] Vogels R, Zuijdgeest D, van Rijnsoever R, Hartkoorn E, Damen I, de Bethune MP, et al. Replication-deficient human adenovirus type 35 vectors for gene transfer and vaccination: efficient human cell infection and bypass of preexisting adenovirus immunity. J Virol 2003;77(15):8263-71.

[48] Szarfman A, Lyon JA, Walliker D, Quakyi I, Howard RJ, Sun S, et al. Mature liver stages of cloned Plasmodium falciparum share epitopes with proteins from sporozoites and asexual blood stages. Parasite Immunol 1988;10(3):339-51.

[49] Egan AF, Morris J, Barnish G, Allen S, Greenwood BM, Kaslow DC, et al. Clinical immunity to Plasmodium falciparum malaria is associated with serum antibodies to the 19-kDa C-terminal fragment of the merozoite surface antigen, PfMSP-1. J Infect Dis 1996;173(3):765-9.

[50] Okech BA, Corran PH, Todd J, Joynson-Hicks A, Uthaipibull C, Egwang TG, et al. Fine specificity of serum antibodies to Plasmodium falciparum merozoite surface protein, PfMSP-1(19), predicts protection from malaria infection and high-density parasitemia. Infect Immun 2004;72(3):1557-67.

[51] Chang SP, Case SE, Gosnell WL, Hashimoto A, Kramer KJ, Tam $\mathrm{LQ}$, et al. A recombinant baculovirus 42-kilodalton C-terminal fragment of Plasmodium falciparum merozoite surface protein 1 protects Aotus monkeys against malaria. Infect Immun 1996;64:25361.

[52] Darko CA, Angov E, Collins WE, Bergmann-Leitner ES, Girouard AS, Hitt SL, et al. Clinical grade Plasmodium falciparum FVO MSP1-42 expressed by Escherichia coli protects Aotus nancymai against homologous erythrocytic-stage challenge. Infect Immun 2005;73:287-97.

[53] Angov E, Aufiero BM, Turgeon AM, Van Handenhove M, Ockenhouse $\mathrm{CF}$, Kester KE, et al. Development and pre-clinical analysis of a Plasmodium falciparum merozoite surface protein-1(42) malaria vaccine. Mol Biochem Parasitol 2003;128(2):195-204.

[54] Pichyangkul S, Gettayacamin M, Miller RS, Lyon JA, Angov E, Tongtawe $\mathrm{P}$, et al. Pre-clinical evaluation of the malaria vaccine candidate $P$. falciparum MSP1(42) formulated with novel adjuvants or with alum. Vaccine 2004;22(29/30):3831-40.

[55] Triglia T, Healer J, Caruana SR, Hodder AN, Anders RF, Cowman AF. Apical membrane antigen 1 plays a central role in erythrocyte invasion by Plasmodium species. Mol Microbiol 2000;38(4):706-18.

[56] Silvie O, Franetich JF, Charrin S, Mueller MS, Siau A, Bodescot $\mathrm{M}$, et al. A role for apical membrane antigen 1 during invasion of hepatocytes by Plasmodium falciparum sporozoites. J Biol Chem 2004;279(10):9490-6.

[57] Krzych U, Lyon JA, Jareed T, Schneider I, Hollingdale MR, Gordon $\mathrm{DM}$, et al. T lymphocytes from volunteers immunized with irradiated Plasmodium falciparum sporozoites recognize liver and blood stage malaria antigens. J Immunol 1995;155(8):4072-7.

[58] Polley SD, Mwangi T, Kocken CH, Thomas AW, Dutta S, Lanar DE, et al. Human antibodies to recombinant protein constructs of Plasmodium falciparum apical membrane antigen 1 (AMA1) and their associations with protection from malaria. Vaccine 2004;23(5):718-28.

[59] Anders RF, Crewther PE, Edwards S, Margetts M, Matthew ML, Pollock B, et al. Immunisation with recombinant AMA-1 protects mice against infection with Plasmodium chabaudi. Vaccine 1998;16(2/3):240-7.

[60] Stowers AW, Kennedy MC, Keegan BP, Saul A, Long CA, Miller LH. Vaccination of monkeys with recombinant Plasmodium falciparum apical membrane antigen 1 confers protection against bloodstage malaria. Infect Immun 2002;70(12):6961-7.

[61] Dutta S, Lalitha PV, Ware LA, Barbosa A, Moch JK, Vassell MA, et al. Purification, characterization, and immunogenicity of the refolded 
ectodomain of the Plasmodium falciparum apical membrane antigen 1 expressed in Escherichia coli. Infect Immun 2002;70(6):3101-10. [62] Hollingdale MR, Aikawa M, Atkinson CT, Ballou WR, Chen GX, $\mathrm{Li} \mathrm{J}$, et al. Non-CS pre-erythrocytic protective antigens. Immunol Lett 1990;25(1-3):71-6.
[63] Kurtis JD, Hollingdale MR, Luty AJ, Lanar DE, Krzych U, Duffy PE. Pre-erythrocytic immunity to Plasmodium falciparum: the case for an LSA-1 vaccine. Trends Parasitol 2001;17(5):219-23.

[64] http://www.malariavaccine.org/files/FS_WRAIR_LSA1-November2004_FINAL.pdf (cited 29 December 2004). 